\title{
Microbacterium binotii sp. nov., isolated from human blood
}

\author{
Correspondence \\ D. Clermont \\ dclermon@pasteur.fr
}

\author{
D. Clermont, ${ }^{1}$ S. Diard, ${ }^{1}$ C. Bouchier, ${ }^{2}$ C. Vivier, ${ }^{1}$ F. Bimet, ${ }^{1}$ L. Motreff, ${ }^{3}$ \\ M. Welker, ${ }^{4}$ W. Kallow ${ }^{4}$ and C. Bizet ${ }^{1,3}$ \\ ${ }^{1}$ Collection de l'Institut Pasteur (CIP), Paris, France \\ ${ }^{2}$ Plate-Forme Génomique, Pasteur Genopole lle de France, Institut Pasteur, Paris, France \\ ${ }^{3}$ Centre de Ressources Biologiques de I'Institut Pasteur, Paris, France \\ ${ }^{4}$ AnagnosTec, Potsdam-Golm, Germany
}

Orla-Jensen (1919) first established the genus Microbacterium, with only four species. At the time of writing, the genus includes 60 species. It has always been recognized that the genus Microbacterium is heterogeneous. Some species of the genera Brevibacterium (Collins et al., 1983; Schumann et al., 1999) and Flavobacterium (Imai et al., 1984; Takeuchi \& Hatano, 1998a) have been reclassified as species of the genus Microbacterium, and a comparative sequence analysis of the $16 \mathrm{~S}$ rRNA gene revealed that the genera Microbacterium and Aureobacterium should be unified (Takeuchi \& Hatano, 1998b; Behrendt et al., 2001). Members of the genus Microbacterium have been isolated mainly from environmental habitats. Here, we describe the phenotypic and genotypic properties of a novel species of the genus Microbacterium, isolated from human blood.

Strains CIP $101303^{\mathrm{T}}$ and CIP 102116 from the Collection de l'Institut Pasteur were isolated from human blood in 1976 and 1977, respectively, and identified as belonging to the genus Microbacterium. They were grown aerobically at $30{ }^{\circ} \mathrm{C}$ on trypto-casein-soy agar (Bio-Rad) and previously

Abbreviation: MALDI-TOF, matrix-assisted laser desorption/ionization time-of-flight.

The GenBank/EMBL/DDBJ accession numbers for the 16S rRNA gene sequences of strains CIP $101303^{\top}$ and CIP 102116 are EF567306 and EU600175, respectively. examined by the conventional tests described by Renaud et al. (2007). Enzyme reactions and acid-producing abilities were studied by means of the API ZYM and API $50 \mathrm{CH}$ systems (bioMérieux), respectively. These systems were used as recommended by the manufacturer. Physiological and biochemical characteristics were found to be identical for strain CIP $101303^{\mathrm{T}}$ and strain CIP 102116 (Table 1).

CIP $101303^{\mathrm{T}}$ and CIP 102116 were subjected to matrixassisted laser desorption/ionization time-of-flight (MALDI-TOF) mass spectrometry followed by spectral analysis using the SARAMIS software and database tools (Spectral Archive And Microbial Identification System; AnagnosTec). Mass spectral analysis of intact cells has evolved to provide an efficient tool for the identification of micro-organisms on various taxonomic levels (Fenselau \& Demirev, 2001) and allows dereplication of novel isolates (Dieckmann et al., 2005) and taxonomic revisions (Stackebrandt et al., 2005). The methodology is based on the detection of abundant structural proteins, such as ribosomal proteins or DNA-binding proteins (Ryzhov \& Fenselau, 2001; Fagerquist et al., 2005), generating taxonspecific patterns (Valentine et al., 2005). Various mathematical methods have been developed to compare mass spectra and to construct trees based on pattern similarity (Jarman \& Wahl, 2006). Fresh cells were transferred directly from agar plates to a MALDI-TOF mass spectro- 
Table 1. Phenotypic characteristics of strains CIP $101303^{\top}$, CIP 102116 and M. halotolerans CIP $108071^{\top}$

Strains: 1, CIP $101303^{\mathrm{T}}$; 2, CIP 102116; 3, M. halotolerans CIP $108071^{\mathrm{T}}$. Data are from this study. + , Positive; - , negative.

\begin{tabular}{|lccc|}
\hline Characteristic & $\mathbf{1}$ & $\mathbf{2}$ & $\mathbf{3}$ \\
\hline Colony colour & Yellow & Yellow & White \\
Starch hydrolysis & + & + & - \\
Enzyme activity & & & \\
$\quad \alpha$-Galactosidase & + & + & - \\
$\quad N$-Acetyl- $\beta$-glucosaminidase & + & + & - \\
Acid production from: & & & \\
$\quad$ Glycerol & + & + & - \\
L-Arabinose & + & + & - \\
Lactose & + & + & - \\
Trehalose & + & + & - \\
\hline
\end{tabular}

meter sample plate (stainless steel, 100 wells) by using a sterile pipette tip. For extraction, the samples were mixed immediately with $1 \mu \mathrm{l}$ matrix solution (75 mg 2,5dihydroxybenzoic acid $\mathrm{ml}^{-1}$ in $50 \%$ acetonitrile with $0.3 \%$ trifluoroacetic acid) and allowed to co-crystallize at room temperature. Mass spectrometric measurements were taken on a Voyager-DE PRO Workstation (Applied Biosystems) with manual data acquisition as described by Stackebrandt et al. (2005).

For several of the Microbacterium strains, series of peaks with high intensities and an intermittent distance of $128 \mathrm{Da}$ were detected, indicating the presence of polyglutamine. As the presence and intensity of respective mass signals are subject to physiological conditions to a high degree, they have limited value as taxonomic biomarkers. Therefore, all mass spectra were filtered with an exclusion list containing the series of polyglutamine masses.

MALDI-TOF mass spectrometry of the Microbacterium strains under study yielded mass spectra with some 30-50 distinct signals in the range of 3-5 kDa. Fig. 1 shows typical mass spectra of four species, including CIP $101303^{\mathrm{T}}$, in which peaks of a polyglutamine compound predominate in the lower mass range. Polyglutamine was also detected in strain CIP 102116 and in the type strains of Microbacterium thalassium (CIP $105728^{\mathrm{T}}$ ), Microbacterium testaceum (CIP $\left.104324^{\mathrm{T}}\right)$, Microbacterium aurum (CIP 103994 ${ }^{\mathrm{T}}$ ) and Microbacterium flavescens (CIP $102401^{\mathrm{T}}$ ) (data not shown).

Mass spectra of the Microbacterium strains were found to be rather variable and only a few mass signals were found with frequencies of $50 \%$ or higher. The dendrogram (Fig. 2) resulting from the dataset shows that CIP $101303^{T}$ and CIP 102116 were separated from all other strains at a level of $20-30 \%$ similarity, whilst the similarity between these two strains was approximately $56 \%$. Further investigation was consequently performed on these two strains.

The 16S rRNA genes from the two strains studied were amplified by PCR using the universal primers A,

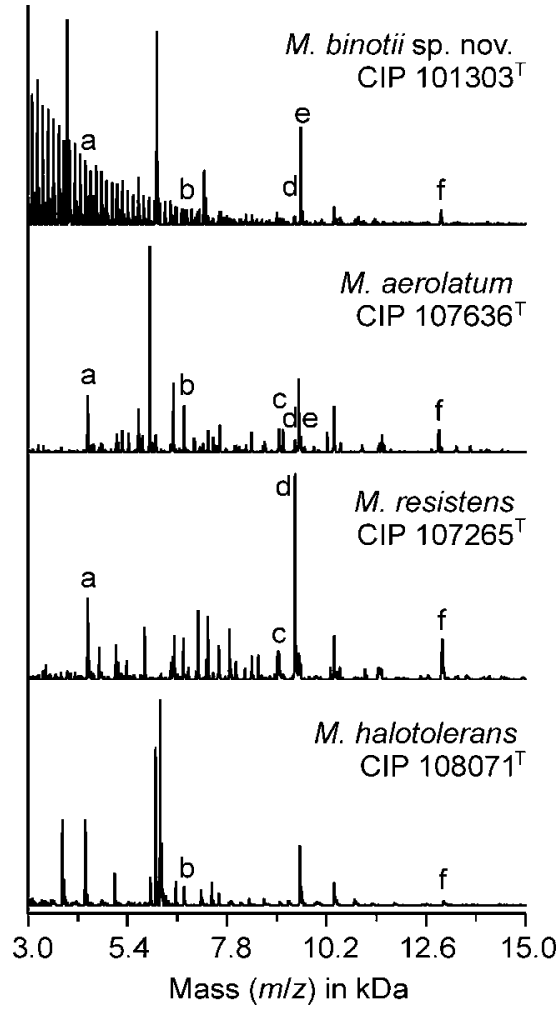

Fig. 1. Typical MALDI-TOF mass spectra of Microbacterium strains. Letters above peaks indicate mass signals that are present in multiple strains. In the mass spectrum of CIP $101303^{\top}$, a series of peaks in the lower mass range could be identified as polyglutamine.

5'-AGAGTTTGATCATGGCTCAG-3' (position 8-27, Escherichia coli numbering system), and $\mathrm{H}, 5^{\prime}-$ AAGGAGGTGATCCAACCGCA-3' (1541-1522) (Böttger, 1989), in a GeneAmp thermal cycler (Perkin-Elmer) with the following cycle parameters: $4 \mathrm{~min}$ at $94{ }^{\circ} \mathrm{C} ; 25$ cycles of 1 min at $94{ }^{\circ} \mathrm{C}, 1$ min at $57^{\circ} \mathrm{C}$ and 2 min at $72{ }^{\circ} \mathrm{C}$; with a final extension step at $72{ }^{\circ} \mathrm{C}$ for $5 \mathrm{~min}$. Each PCR product was purified by filtration on P100 Gel Fine (Bio-Rad) and sequenced using primers $\mathrm{A}, \mathrm{H}$ and eight other sequencing primers (E. coli numbering system): B, 5'-CTCCTACGGGAGGCAGCAGT-3' (339-358); C, 5' -ACTGCTGCCTCCCGTAGGAG-3' (358-339); D, 5' -CGTGCCAGCAGCCGCGGTAAT-3' (514-534); E, 5' -TTACCGCGGCTGCTGGCACGT-3' (533-514); F， 5'-GATTAGATACCCTGGTAG-3' (786-803); G, 5'-GCATGTGGTTTAATTCGA-3' (947-964); I, 5'-TCGAATTAAACCACATGC-3' (964-947); and J, 5'-AGGGTTGCGCTCGTTGCGG-3' (1115-1097). A BigDye Terminator cycle sequencing kit and ABI PRISM 3700 DNA sequencer were used according to the manufacturer's instructions (Applied Biosystems). The almost-complete sequences of the 16S rRNA gene from CIP $101303^{\mathrm{T}}$ (1406 nt) and CIP 102116 (1365 nt) were obtained by using the script Assembler Tool Kit developed 


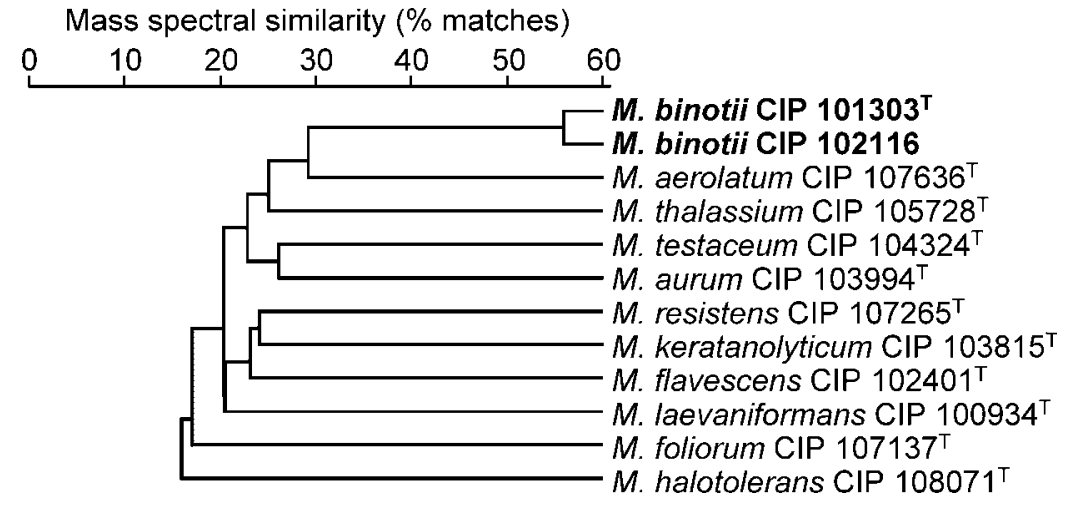

Fig. 2. Dendrogram of Microbacterium strains calculated by SARAMIS based on mass spectral fingerprints in the range of 3000-15000 Da. by Eric Deveaud and Betina Setterblad, Groupe Logiciels et Banques de Données, Institut Pasteur.

$16 \mathrm{~S}$ rRNA gene sequence similarity was $100 \%$ between strains CIP $101303^{\mathrm{T}}$ and CIP 102116 and ranged from 96 to $98 \%$ between these two strains and all of the other type strains of Microbacterium species under study. According to Stackebrandt \& Goebel (1994), organisms displaying $<97 \% \quad 16 \mathrm{~S}$ rRNA gene sequence similarity can be considered as not belonging to the same species. However, it has been already noted that several Microbacterium species show $<3 \%$ similarity between their 16S rRNA gene sequences (Ko et al., 2007). The characteristics that distinguish the two novel strains from related Microbacterium species are listed in Table 2.

Phylogenetic analysis based on the 16S rRNA gene sequences of strains CIP $101303^{\mathrm{T}}$, CIP 102116 and type strains of species belonging to the genus Microbacterium, mostly retrieved from GenBank, was performed after elimination of poor alignment and gaps by using the Gblocks method (Castresana, 2000). The sequences were aligned with CLUSTALX (Thompson et al., 1997). A distance matrix was constructed by using the Jukes-Cantor algorithm with DNADIST. A phylogenetic tree was constructed by using the neighbour-joining method (Saitou \& Nei, 1987) using PHYLIP version 3.6 and viewed by using NJPLOT (Perrière \& Gouy, 1996). The stability of the grouping was estimated by bootstrap analysis (100 replications) using the PHYLIP package (Felsenstein, 1989).

The phylogenetic tree constructed by the neighbourjoining method indicated that the two isolates formed a distinct cluster within the genus Microbacterium (Fig. 3). The resulting topologies were then investigated by using the maximum-parsimony (Felsenstein, 1989) and maximum-likelihood (Guindon \& Gascuel, 2003) methods, and the two strains that could not be assigned to a described species always formed a distinct cluster, with Microbacterium halotolerans as the nearest phylogenetic neighbour (Fig. 3).

Chemotaxonomic analyses for strains CIP $101303^{\mathrm{T}}$ and CIP 102116 were carried out by the Identification Service of the Deutsche Sammlung von Mikroorganismen und
Zellkulturen (DSMZ), Braunschweig, Germany (Table 3). The predominant menaquinones were MK-10, MK-11 and MK-12. The polar lipids comprised diphosphatidylglycerol, phosphatidylglycerol, an unknown glycolipid and unknown phospholipids. GC analysis of cellular fatty acid methyl esters was performed by using the Sherlock MIDI system (Sasser, 1990), following the protocol of the Microbial Identification System (MIDI, 1999). The major fatty acids of strains CIP $101303^{\mathrm{T}}$ and CIP 102116 were anteiso- $\mathrm{C}_{15: 0}$, iso- $\mathrm{C}_{16: 0}$ and anteiso- $\mathrm{C}_{17: 0}$. The cellular fatty acid profile was consistent with those of other members of the genus Microbacterium. Cell-wall sugars were obtained according to the method of Whiton et al. (1985) and the samples were analysed by TLC on cellulose plates as described by Staneck \& Roberts (1974). The cellwall sugars were galactose, mannose and rhamnose. The amino acid composition of the cell-wall peptidoglycan was determined after hydrolysis with $4 \mathrm{M} \mathrm{HCl}$ at $100{ }^{\circ} \mathrm{C}$ for $16 \mathrm{~h}$ as described by Schleifer (1985). Cell-wall peptidoglycan of CIP $101303^{\mathrm{T}}$ and CIP 102116 contained ornithine, alanine, glycine, homoserine (Hsr), glutamic acid and hydroxyglutamic acid (Hyg). From these data, it was concluded that the peptidoglycan was of type B6: B2 $\beta$ \{Gly\} [L-Hsr] D-Glu(Hyg)-Gly-D-Orn (Schleifer \& Kandler, 1972). This estimated structure was that of the genus Aureobacterium, which is now unified with the genus Microbacterium (Takeuchi \& Hatano, 1998b). The phylogenetic significance of peptidoglycan types in the genus Microbacterium has recently been demonstrated (Richert et al., 2007). In conclusion, all of these chemotaxonomic results are in accordance with the description of the genus Microbacterium (Takeuchi \& Hatano, 1998b).

The $\mathrm{G}+\mathrm{C}$ content of the DNA was determined by the Identification Service of the DSMZ by reverse-phase HPLC of nucleosides according to Mesbah et al. (1989). The DNA $\mathrm{G}+\mathrm{C}$ contents of CIP $101303^{\mathrm{T}}$ and CIP 102116 were 71.7 and $70.4 \mathrm{~mol} \%$, respectively (Table 3 ). These correspond with those of the members of the genus Microbacterium, which have high DNA G $+\mathrm{C}$ contents of 66.5-71.6 mol\% (Takeuchi \& Hatano, 1998b).

DNA-DNA hybridization to determine genomic relatedness was performed by the DSMZ as described by De Ley 
Table 2. Differential characteristics between strain CIP $101303^{\top}$ and the type strains of its nearest phylogenetic neighbours

Species: 1, M. binotii; 2, M. halotolerans; 3, M. trichothecenolyticum; 4, M. halophilum; 5, M. xylanilyticum; 6, M. hominis; 7, M. thalassium; 8, M. terrae; 9, M. ketosireducens; 10, M. flavescens; 11, M. laevaniformans; 12, M. dextranolyticum; 13, M. chocolatum; 14, M. aurantiacum; 15, M. kitamiense. Data represent the type strain of each species and are from this study, Takeuchi \& Hatano (1998a, b), Behrendt et al. (2001), Kim et al. (2005) and Matsuyama et al. (1999). +, Positive; -, negative; ND, not determined; 6dT, 6-deoxytalose; Fuc, fucose; Glc, glucose; Gal, galactose; Man, mannose; Rha, rhamnose; Rib, ribose; Xyl, xylose.

\begin{tabular}{|c|c|c|c|c|c|c|c|c|c|c|c|c|c|c|c|}
\hline Characteristic & 1 & 2 & 3 & 4 & 5 & 6 & 7 & 8 & 9 & 10 & 11 & 12 & 13 & 14 & 15 \\
\hline Colony colour & Yellow & White & Yellow & Yellow & Yellow & $\begin{array}{l}\text { Yellow- } \\
\text { white }\end{array}$ & Yellow & Yellow & Yellow & Yellow & Yellow & Yellow & Orange & Orange & Orange \\
\hline Growth at $37^{\circ} \mathrm{C}$ & + & + & - & + & + & + & - & - & - & - & + & - & + & + & + \\
\hline $\mathrm{H}_{2} \mathrm{~S}$ production & - & - & + & - & $\mathrm{ND}$ & + & - & + & + & + & + & + & + & + & - \\
\hline Voges-Proskauer test & - & - & - & - & + & + & - & - & - & - & + & + & - & - & - \\
\hline $\begin{array}{l}\text { DNA G + C content } \\
(\mathrm{mol} \%)\end{array}$ & 71.7 & 66.5 & 69 & 67.2 & 69.7 & 71.2 & 69.7 & 70.7 & 69.8 & 66.9 & 68.8 & 68.3 & 69.5 & 70.3 & 69.2 \\
\hline Major menaquinones & $\begin{array}{c}\text { MK-11, } \\
\text { MK-12, } \\
\text { MK-13 }\end{array}$ & $\begin{array}{r}\text { MK-10, } \\
\text { MK-11 }\end{array}$ & $\begin{array}{r}\text { MK-12, } \\
\text { MK-13 }\end{array}$ & $\begin{array}{c}\text { MK-11, } \\
\text { MK-12, } \\
\text { MK-13 }\end{array}$ & $\begin{array}{c}\mathrm{MK}-11, \\
\mathrm{MK}-12, \\
\mathrm{MK}-13\end{array}$ & $\begin{array}{r}\text { MK-11, } \\
\text { MK-12 }\end{array}$ & $\begin{array}{r}\text { MK-11, } \\
\text { MK-12 }\end{array}$ & $\begin{array}{r}\text { MK-13, } \\
\text { MK-14 }\end{array}$ & MK-13 & $\begin{array}{r}\text { MK-13, } \\
\text { MK-14 }\end{array}$ & $\begin{array}{r}\mathrm{MK}-11 \\
\mathrm{MK}-12\end{array}$ & $\begin{array}{r}\text { MK-11, } \\
\text { MK-12 }\end{array}$ & MK-12 & MK-12 & $\begin{array}{r}\text { MK-11, } \\
\text { MK-12 }\end{array}$ \\
\hline $\begin{array}{l}\text { Cell-wall } \\
\text { diamino acid }\end{array}$ & Orn & Orn & Orn & Orn & Orn & Lys & Orn & Orn & Orn & Orn & Lys & Lys & Orn & Orn & Orn \\
\hline Peptidoglycan & $\mathrm{B} 2 \beta$ & $\mathrm{B} 2 \beta$ & $\mathrm{B} 2 \beta$ & $\mathrm{B} 2 \beta$ & $\mathrm{B} 2 \beta$ & $\mathrm{B} 1 \alpha$ & B2 $\beta$ & $\mathrm{B} 2 \beta$ & $\mathrm{B} 2 \beta$ & $\mathrm{B} 2 \beta$ & $\mathrm{B} 1 \alpha$ & $\mathrm{B} 1 \alpha$ & $\mathrm{B} 2 \beta$ & $\mathrm{B} 2 \beta$ & $\mathrm{ND}$ \\
\hline Major cell-wall sugars & $\begin{array}{l}\text { Man, } \\
\text { Gal, Rha }\end{array}$ & $\begin{array}{l}\text { Rib, Gal, } \\
\text { Glc, Xyl }\end{array}$ & Gal, Glc & $\begin{array}{c}\text { Man, Gal, } \\
\text { Glc }\end{array}$ & Gal, Glc & $\begin{array}{c}\text { Rha, 6dT, } \\
\text { Gal, } \\
\text { Man }\end{array}$ & Gal, Glc & $\begin{array}{l}\text { Rha, } \\
\text { Gal, } \\
\text { Glc }\end{array}$ & $\mathrm{ND}$ & $\begin{array}{c}\text { Rha, Gal, } \\
\text { Glc }\end{array}$ & $\begin{array}{l}\text { Rha, Gal, } \\
\text { Xyl, Man }\end{array}$ & $\begin{array}{c}\text { 6dT, Gal, } \\
\text { Man }\end{array}$ & $\begin{array}{c}\text { Rha, Gal, } \\
\text { Man }^{*} \\
\mathrm{Xyl}^{*}\end{array}$ & $\begin{array}{c}\text { Rha, Gal, } \\
\text { Fuc }\end{array}$ & $\begin{array}{l}\text { Rha, } \\
\text { Gal, } \\
\text { Glc, } \\
\text { Man }\end{array}$ \\
\hline
\end{tabular}

${ }^{\star}$ Trace. 


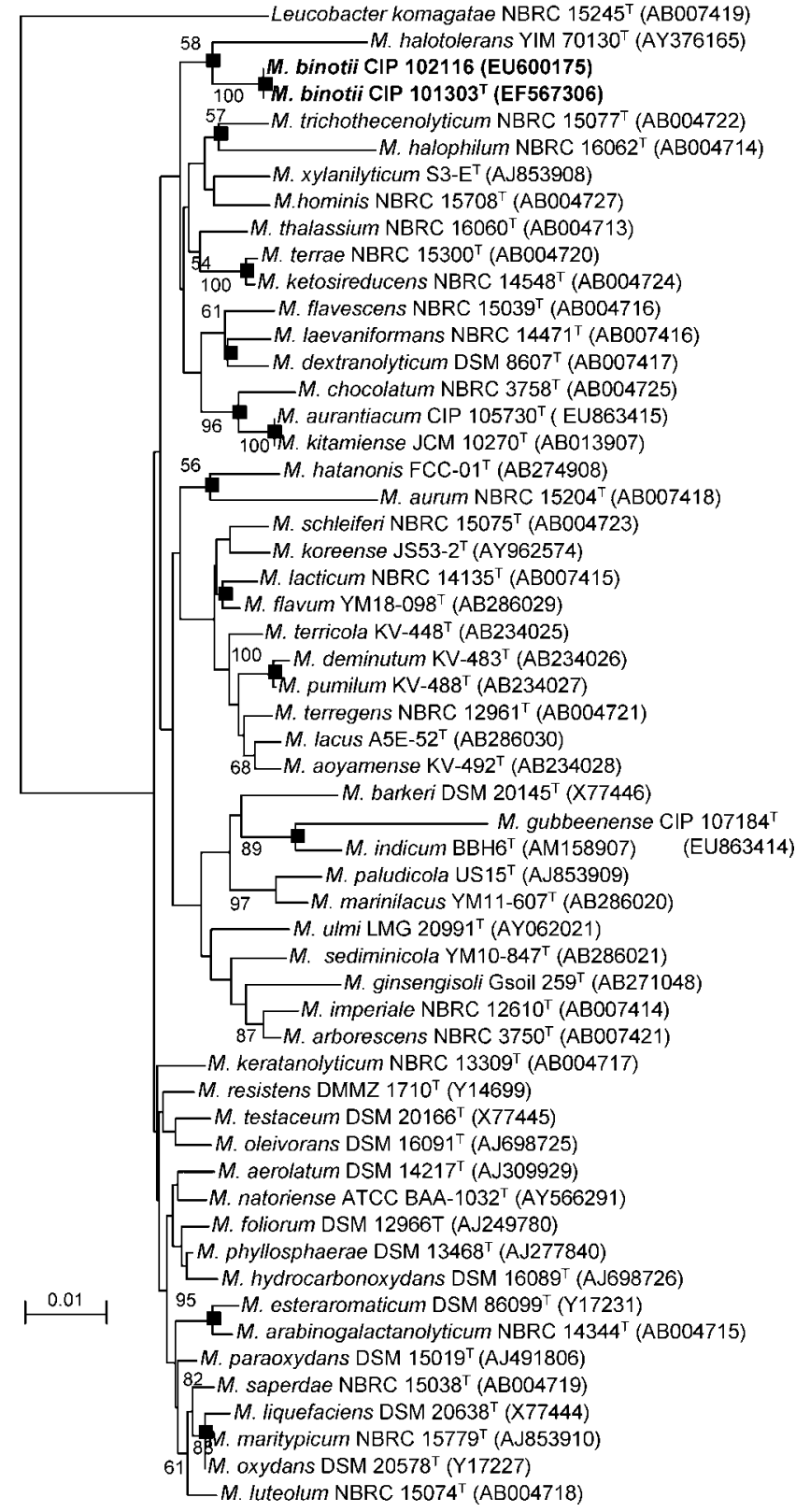

Fig. 3. Phylogenetic tree based on $16 \mathrm{~S}$ rRNA gene sequences using the neighbour-joining method, showing the position of the proposed M. binotii strains (CIP 101303 ${ }^{\top}$ and CIP 102116) in relation to type strains of species in the genus Microbacterium. Leucobacter komagatae NBRC $15245^{\top}$ was used as outgroup. Bootstrap values (\%) are based on 100 replicates and are shown for branches with $>50 \%$ boostrap support. $\mathbf{a}$ indicates that the corresponding node was also recovered in the trees generated by the maximum-parsimony and maximum-likelihood methods (data not shown). Bar, 1 substitution per $100 \mathrm{nt}$.

et al. (1970), with consideration of the modifications described by Huß et al. (1983), using a model Cary 100 Bio UV/VIS spectrophotometer equipped with a Peltierthermostatted $6 \times 6$ multicell changer and a temperature controller with an in situ temperature probe (Varian). $M$. halotolerans CIP $108071^{\mathrm{T}}$ was also used for this experiment. The DNA-DNA hybridization value between CIP $101303^{\mathrm{T}}$ and CIP 102116 was $77.1 \%$ and that between CIP $101303^{\mathrm{T}}$ and M. halotolerans CIP $108071^{\mathrm{T}}$ was $22.4 \%$. When the recommendation of a threshold value of $70 \%$ for DNADNA relatedness for the definition of bacterial species (Wayne et al., 1987) is considered, these results suggest strongly that the two strains represent a novel species of the genus Microbacterium.

Thus, based on the phenotypic and genotypic characteristics of strains CIP $101303^{\mathrm{T}}$ and CIP 102116 and the differences observed from their nearest phylogenetic neighbours (Table 2), both strains should indeed be considered as belonging to a novel species and we accordingly propose Microbacterium binotii sp. nov., with CIP $101303^{\mathrm{T}}$ as the type strain.

\section{Description of Microbacterium binotii sp. nov.}

Microbacterium binotii (bi.no'ti.i. N.L. gen. n. binotii of Binot, named in honour of Dr Binot, who created the Collection de l'Institut Pasteur).

Aerobic, Gram-positive, non-motile, non-spore-forming, short rods. Colonies are yellow, circular and approximately $1-2 \mathrm{~mm}$ in diameter after $48 \mathrm{~h}$ at $30^{\circ} \mathrm{C}$. Can grow on trypto-casein-soy agar with $0-6 \% \mathrm{NaCl}$. Can grow at $15-$ $37^{\circ} \mathrm{C}$. Positive for catalase. Negative for oxidase. Starch is decomposed, but gelatin and casein are not. VogesProskauer and indole-production tests are negative. Nitrate is not reduced to nitrite. Positive for esterase, acid phosphatase, $\alpha$-galactosidase, $\beta$-galactosidase, $N$-acetyl- $\beta$ glucosaminidase and $\alpha$ - and $\beta$-glucosidase activities. Negative for ornithine decarboxylase, arginine dihydrolase, lysine decarboxylase, urease, trypsin, $\beta$-glucuronidase, $\alpha$ mannosidase and $\alpha$-fucosidase activities. Acid is produced from glycerol, L-arabinose, D-xylose, galactose, D-glucose, D-fructose, D-mannose, mannitol, arbutin, aesculin, salicin, cellobiose, maltose, lactose, sucrose, trehalose, starch, $\beta$ gentiobiose, turanose and gluconate. Predominant menaquinones are MK-10, MK-11 and MK-12. Major fatty acids are anteiso- $\mathrm{C}_{15: 0}$, iso- $\mathrm{C}_{16: 0}$ and anteiso- $\mathrm{C}_{17: 0}$. Cell-wall sugars are galactose, mannose and rhamnose and the diamino acid in the cell-wall peptidoglycan is ornithine. The polar lipids comprise diphosphatidylglycerol, phosphatidylglycerol, an unknown glycolipid and unknown phospholipids. The DNA G + C content is $70-72 \mathrm{~mol} \%$.

The type strain is CIP $101303^{\mathrm{T}}\left(=\mathrm{DSM} 19164^{\mathrm{T}}\right)$ and was isolated from human blood in Suresnes, France, in 1976.

\section{Acknowledgements}

We wish to thank Dr J. P. Euzéby for his help with the Latin construction of the species name. Also, the assistance of Dr Marcel Erhard and Dr Ines Streit with mass spectral analyses is acknowledged. 
Table 3. Chemotaxonomic characteristics of strains CIP $101303^{\top}$, CIP 102116 and M. halotolerans $\mathrm{YIM}^{70130^{\top}}$

Strains: 1, CIP $101303^{\mathrm{T}}$; 2, CIP 102116; 3, M. halotolerans YIM $70130^{\mathrm{T}}$ (data from Li et al., 2005). Fatty acid composition data are shown as the percentage of total fatty acids. Glc, Glucose; Gal, galactose; Man, mannose; Rha, rhamnose; Rib, ribose; Xyl, xylose; -, not detected or <1 \%; ND, no data available; DPG, diphosphatidylglycerol; GL, glycolipid; PG, phosphatidylglycerol; PL, phospholipid.

\begin{tabular}{|lccc|}
\hline Characteristic & $\mathbf{1}$ & $\mathbf{2}$ & $\mathbf{3}$ \\
\hline DNA G+C content (mol\%) & 71.7 & 70.4 & 66.5 \\
Peptidoglycan & $\mathrm{B} 2 \beta$ & $\mathrm{B} 2 \beta$ & $\mathrm{B} 2 \beta$ \\
Cell-wall sugars & Gal, Man, Rha & Gal, Man, Rha & Rib, Gal, Glc, Xyl \\
Cell-wall diamino acid & Orn & Orn & Orn \\
Major menaquinones $\dagger$ & MK-10, MK-11, MK-12 & MK-10, MK-11, MK-12 & MK-10, MK-11 \\
Fatty acid composition & & & 1.19 \\
iso-C $15: 0$ & - & 27.33 & 39.91 \\
anteiso-C $15: 0$ & 22.42 & 15.20 & 23.40 \\
iso-C $16: 0$ & 17.34 & 5.13 & 1.97 \\
$\mathrm{C}_{16: 0}$ & 7.25 & 50.44 & 30.07 \\
anteiso-C $17: 0$ & 50.65 & PG, DPG, PL, GL & ND \\
Polar lipids $\dagger$ & PG, DPG, PL, GL & \\
\hline
\end{tabular}

${ }^{\star}$ Trace.

$\dagger$ Analyses performed by Dr B. J. Tindall, DSMZ.

\section{References}

Behrendt, U., Ulrich, A. \& Schumann, P. (2001). Description of Microbacterium foliorum sp. nov. and Microbacterium phyllosphaerae sp. nov., isolated from the phyllosphere of grasses and the surface litter after mulching the sward, and reclassification of Aureobacterium resistens (Funke et al. 1998) as Microbacterium resistens comb. nov. Int J Syst Evol Microbiol 51, 1267-1276.

Böttger, E. C. (1989). Rapid determination of bacterial ribosomal RNA sequences by direct sequencing of enzymatically amplified DNA. FEMS Microbiol Lett 53, 171-176.

Castresana, J. (2000). Selection of conserved blocks from multiple alignments for their use in phylogenetic analysis. Mol Biol Evol 17, 540-552.

Collins, M. D., Jones, D. \& Kroppenstedt, R. M. (1983). Reclassification of Brevibacterium imperiale (Steinhaus) and "Corynebacterium laevaniformans" (Dias and Bhat) in a redefined genus Microbacterium (Orla-Jensen), as Microbacterium imperiale comb. nov. and Microbacterium laevaniformans nom. rev.; comb. nov. Syst Appl Microbiol 4, 65-78.

De Ley, J., Cattoir, H. \& Reynaerts, A. (1970). The quantitative measurement of DNA hybridization from renaturation rates. Eur $J$ Biochem 12, 133-142.

Dieckmann, R., Graeber, I., Kaesler, I., Szewzyk, U. \& von Döhren, H. (2005). Rapid screening and dereplication of bacterial isolates from marine sponges of the Sula Ridge by Intact-Cell-MALDI-TOF mass spectrometry (ICM-MS). Appl Microbiol Biotechnol 67, 539-548.

Fagerquist, C. K., Miller, W. G., Harden, L. A., Bates, A. H., Vensel, W. H., Wang, G. \& Mandrell, R. E. (2005). Genomic and proteomic identification of a DNA-binding protein used in the "fingerprinting" of Campylobacter species and strains by MALDI-TOF-MS protein biomarker analysis. Anal Chem 77, 4897-4907.

Felsenstein, J. (1989). PHYLIP - phylogeny inference package (version 3.2). Cladistics 5, 164-166.

Fenselau, C. \& Demirev, P. A. (2001). Characterization of intact microorganisms by MALDI mass spectrometry. Mass Spectrom Rev 20, 157-171.
Guindon, S. \& Gascuel, O. (2003). A simple, fast and accurate algorithm to estimate large phylogenies by maximum likelihood. Syst Biol 52, 696-704.

Huß, V. A. R., Festl, H. \& Schleifer, K. H. (1983). Studies on the spectrophotometric determination of DNA hybridization from renaturation rates. Syst Appl Microbiol 4, 184-192.

Imai, K., Takeuchi, M. \& Banno, I. (1984). Reclassification of "Flavobacterium arborescens" (Frankland and Frankland) Bergey et al. in the genus Microbacterium (Orla-Jensen) Collins et al., as Microbacterium arborescens comb. nov., nom. rev. Curr Microbiol 11, 281-284.

Jarman, K. H. \& Wahl, K. L. (2006). Development of spectral patternmatching approaches to matrix assisted laser desorption/ionization time-of-flight mass spectrometry for bacterial identification. In Identification of Microorganisms by Mass Spectrometry, pp. 153-160. Edited by C. L. Wilkins \& J. O. Lay. Hoboken, NJ: Wiley.

Kim, K. K., Park, H. Y., Park, W., Kim, I. S. \& Lee, S. T. (2005). Microbacterium xylanilyticum sp. nov., a xylan-degrading bacterium isolated from a biofilm. Int J Syst Evol Microbiol 55, 2075-2079.

Ko, K. S., Oh, W. S., Lee, M. Y., Peck, K. R., Lee, N. Y. \& Song, J.-H. (2007). A new Microbacterium species isolated from the blood of a patient with fever: Microbacterium pyrexiae sp. nov. Diagn Microbiol Infect Dis 57, 393-397.

Li, W.-J., Chen, H.-H., Kim, C.-J., Park, D.-J., Tang, S.-K., Lee, J.-C., Xu, L.-H. \& Jiang, C.-L. (2005). Microbacterium halotolerans sp. nov., isolated from a saline soil in the west of China. Int J Syst Evol Microbiol 55, 67-70.

Matsuyama, H., Kawasaki, K., Yumoto, I. \& Shida, O. (1999). Microbacterium kitamiense sp. nov., a new polysaccharide-producing bacterium isolated from the wastewater of a sugar-beet factory. Int $\mathrm{J}$ Syst Evol Microbiol 49, 1353-1357.

Mesbah, M., Premachandran, U. \& Whitman, W. B. (1989). Precise measurement of the $\mathrm{G}+\mathrm{C}$ content of deoxyribonucleic acid by highperformance liquid chromatography. Int J Syst Bacteriol 39, 159-167.

MIDI (1999). Sherlock Microbial Identification System, operating manual, version 3.0. Newark, DE: MIDI, Inc. 
Orla-Jensen, S. (1919). The Lactic Acid Bacteria. Copenhagen: Host \& Sons.

Perrière, G. \& Gouy, M. (1996). WWW-Query: an on-line retrieval system for biological sequence banks. Biochimie 78, 364-369.

Renaud, F., Borrel, T. \& Marmonier, A. (2007). Identification conventionnelle. In Précis de Bactériologie Clinique, 2nd edn, pp. 67-108. Edited by J. Freney, F. Renaud, R. Leclercq \& P. Riegel. Paris: Editions ESKA (in French).

Richert, K., Brambilla, E. \& Stackebrandt, E. (2007). The phylogenetic significance of peptidoglycan types: molecular analysis of the genera Microbacterium and Aureobacterium based upon sequence comparison of $g y r B, r p o B, r e c A$ and $p p k$ and $16 \mathrm{~S}$ rRNA genes. Syst Appl Microbiol 30, 102-108.

Ryzhov, V. \& Fenselau, C. (2001). Characterization of the protein subset desorbed by MALDI from whole bacterial cells. Anal Chem 73, 746-750.

Saitou, N. \& Nei, M. (1987). The neighbor-joining method: a new method for reconstructing phylogenetic trees. Mol Biol Evol 4, 406-425.

Sasser, M. (1990). Identification of bacteria by gas chromatography of cellular fatty acids, MIDI Technical Note 101. Newark, DE: MIDI Inc.

Schleifer, K. H. (1985). Analysis of the chemical composition and primary structure of murein. Methods Microbiol 18, 123-156.

Schleifer, K. H. \& Kandler, O. (1972). Peptidoglycan types of bacterial cell walls and their taxonomic implications. Bacteriol Rev 36, 407-477.

Schumann, P., Rainey, F. A., Burghardt, J., Stackebrandt, E. \& Weiss, N. (1999). Reclassification of Brevibacterium oxydans (Chatelain and Second 1966) as Microbacterium oxydans comb. nov. Int J Syst Bacteriol 49, 175177.

Stackebrandt, E. \& Goebel, B. M. (1994). Taxonomic note: a place for DNA-DNA reassociation and $16 \mathrm{~S}$ rRNA sequence analysis in the present species definition in bacteriology. Int J Syst Bacteriol 44, 846-849.
Stackebrandt, E., Päuker, O. \& Erhard, M. (2005). Grouping myxococci (Corallococcus) strains by matrix-assisted laser desorption ionization time-of-flight (MALDI TOF) mass spectrometry: comparison with gene sequence phylogenies. Curr Microbiol 50, 71-77.

Staneck, J. L. \& Roberts, G. D. (1974). Simplified approach to identification of aerobic actinomycetes by thin-layer chromatography. Appl Microbiol 28, 226-231.

Takeuchi, M. \& Hatano, K. (1998a). Proposal of six new species in the genus Microbacterium and transfer of Flavobacterium marinotypicum ZoBell and Upham to the genus Microbacterium as Microbacterium maritypicum comb. nov. Int J Syst Bacteriol 48, 973-982.

Takeuchi, M. \& Hatano, K. (1998b). Union of the genera Microbacterium Orla-Jensen and Aureobacterium Collins et al. in a redefined genus Microbacterium. Int J Syst Bacteriol 48, 739-747.

Thompson, J. D., Gibson, T. J., Plewniak, F., Jeanmougin, F. \& Higgins, D. G. (1997). The CLUSTAL_X windows interface: flexible strategies for multiple sequence alignment aided by quality analysis tools. Nucleic Acids Res 25, 4876-4882.

Valentine, N., Wunschel, S., Wunschel, D., Petersen, C. \& Wahl, K. (2005). Effect of culture conditions on microorganism identification by matrix-assisted laser desorption ionization mass spectrometry. Appl Environ Microbiol 71, 58-64.

Wayne, L. G., Brenner, D. J., Colwell, R. R., Grimont, P. A. D., Kandler, O., Krichevsky, M. I., Moore, L. H., Moore, W. E. C., Murray, R. G. E. \& other authors (1987). International Committee on Systematic Bacteriology. Report of the ad hoc committee on reconciliation of approaches to bacterial systematics. Int J Syst Bacteriol 37, 463-464.

Whiton, R. S., Lau, P., Morgan, S. L., Gilbart, J. \& Fox, A. (1985). Modifications in the alditol acetate method for analysis of muramic acid and other neutral and amino sugars by capillary gas chromatography - mass spectrometry with selected ion monitoring. J Chromatogr 347, 109-120. 